\title{
The Causality Between Agriculture, Industry, and Economic Growth: Evidence from Indonesia
}

\author{
Abdul Bashir ${ }^{*}$, Suhel ${ }^{2}$, Azwardi ${ }^{3}$, Dirta Pratama Atiyatna ${ }^{4}$, \\ Ichsan Hamidi ${ }^{5}$, Nazeli Adnan ${ }^{6}$ \\ *Corresponding author
}

\begin{abstract}
The industry is the current engine of the Indonesian economy over the past three decades; the economic structure in Indonesia has the transformation from the agriculture sector to the industry sector. The objective of this study is to examine the causality between agricultural, industry, and economic growth in Indonesia. By using the vector error correction model (VECM), this research finds that in the long-term, there is directional causality from the industry added value, economic growth on the agricultural added value. Meanwhile, in the short-term, the variable of industry added value and economic growth has the two-way causality. Besides, the agricultural added value can only affect the industrial added value and economic growth in the short-term. These findings support the idea that the agricultural sector plays a vital role in the economy, such as increasing economic growth and growth in other sectors, especially the industrial sector in this case.
\end{abstract}

Keywords: economic growth, agriculture sector, industry sector, VECM

JEL Classification: F40, L60, O13, O47

\begin{abstract}
Abstrak. Mesin perekonomian Indonesia saat ini didasarkan pada industri, selama tiga dekade terakhir, struktur ekonomi di Indonesia memiliki transformasi dari sektor pertanian ke sektor industri. Tujuan penelitian ini adalah untuk menyelidiki hubungan sebab akibat antara pertanian, industri, dan pertumbuhan ekonomi di Indonesia. Dengan menggunakan model koreksi kesalahan vektor (VECM), penelitian ini menunjukkan bahwa dalam jangka panjang terdapat kausalitas searah dari nilai tambah industri, pertumbuhan ekonomi terhadap nilai tambah pertanian. Sementara itu, dalam jangka pendek, variabel nilai tambah industri dan pertumbuhan ekonomi memiliki kausalitas dua arah. Selain itu, nilai tambah pertanian hanya dapat mempengaruhi nilai tambah industri dan pertumbuhan ekonomi dalam jangka pendek. Temuan ini mendukung gagasan bahwa sektor pertanian memainkan peran kunci dalam perekonomian makro, seperti meningkatkan pertumbuhan ekonomi dan pertumbuhan di sektor lain, khususnya sektor industri dalam kasus ini.
\end{abstract}

Kata Kunci: pertumbuhan ekonomi, sektor pertanian, sektor industri, VECM

\section{How to Cite:}

Bashir, A., Suhel., Azwardi., Atiyantna, D. P., Hamidi, I., \& Adnan, N. (2019). The Causality Between Agriculture, Industry, and Economic Growth: Evidence from Indonesia. Etikonomi: Jurnal Ekonomi. Vol. 18 (2): 155 - 168. doi: http//dx.doi.org/10.15408/etk.v18i2.9428. 


\section{Introduction}

Economic development in Indonesia cannot be separated from the role of the agricultural sector (Bashir et al., 2018). However, on the other side, the agricultural sector also depends on providing modern inputs and technology from the industrial sector (Singh, 2010). Meanwhile, the balanced economic structure will achieve if there is advanced industrial capabilities and strengths supported by strong agricultural capabilities and strengths. This condition means that between the agricultural sector and the industrial sector has a strong relationship in improved economic growth, both future linkages and backward linkages in achieving the objectives of each sector.

Several studies reveal that there is a link between the agricultural and industrial sectors seen from the development of processing of agricultural products for the industrial sector (Mondal, 2014; Olmstead \& Rhode, 2007; Souza, 2014). The result of previous studies indicated that there is a process of structural transformation of the economy from agriculture and industry. Various neoclassical economic growth theories and empirical studies of several previous studies indicated that the development of the industrial sector in a country always accompany by improvements in productivity and sustainable growth in the agricultural sector (Cervantes-godoy \& Dewbre, 2010; Kniivilä, 2004). In the case of several developed countries, a thriving agricultural sector is a prerequisite for the development of the industrial and service sector in the future (Briones \& Felipe, 2013). Generally, there are several stages of development; namely, first, development is focused on the development of the agricultural sector and the industry producing agricultural production facilities; second, development focus on the agricultural sector supporting processing industry (agro-industry) which in turn gradually transferred to the construction of machinery and metal industries.

Recent development history shows the evolution of economic development that varies between countries and the existence of relationship and interactions between sectors, for example, the interaction and relations between the agricultural, industrial, and service sectors. Developed countries have a fundamental role in accelerating economic growth. Meanwhile, the role of developed countries is not better compared to oil-producing countries (Sahoo $\&$ Sethi, 2012). The industrial sector development has had a significant role in influencing economic growth as proof that some countries have succeeded in increasing economic growth through equity. However, what happens is that there are high inequalities in the country (Sahoo \& Sethi, 2012). The manufacturing sector usually leads and grows faster than in other fields. However, in low-income countries, the role of manufacturing in GDP is not high, and its direct contribution to small aggregate growth (Loren et al., 2008).

The Industrial Sector employs more people who have experience working in factories than inexperienced farmers (Pingali, 2010). On the other side, according to Awokuse \& Xie (2014) stated that without the growth of the agricultural sector in a country, there would be no country that could develop its industrial sector. Economic growth is the result of complex interactions between all sectors, especially the agricultural, industrial, and service sectors. Each sector has a direct and indirect effect on economic growth based on the policies set in each country. The study that has been carried out by Urbanchuk (2009) that found the 
products produced by the manufacturing sector, such as ethanol production, would provide substantial value to agricultural commodities produced and had contributed significantly to economic growth in the United States.

According to the findings Awokuse \& Xie (2014), the agricultural sector indirectly influences aggregate economic growth, which can provide better calorie nutrition for the poor, stability in food prices, employment opportunities, especially in low-income countries, improving the quality of production factors i.e., capital and labor, and poverty alleviation. Besides, growth theory previously recognized that the agricultural sector as an excellent source to finance the development of the industrial sector (Loren et al., 2008). In contrast to the above argument, advocates of the opposite perspective argue that there is no strong relationship between the agricultural sector and other sectors. In such a sector, an adequate innovative structure is needed only to increase productivity and the higher evolution of exports (Pingali, 2010; Stringer \& Pingali, 2004).

Also, studies that have conducted by Dethier \& Effenberger (2012) that states the relationship between the traditional agricultural sector and modern industry in the overall economic development of a country. Agricultural growth depends on industrial demand for agricultural products. Correspondingly, industrial growth depends on increasing the purchasing power of agricultural land for manufacturing products and providing raw materials for processing. Many developing countries recognize the importance of agricultural land and its role in industrialization for their economic development (Pingali, 2010).

The stages of economic development are expected to form a harmonious and balanced structure of the Indonesian economy, as well as being resilient in facing internal and external turmoil (Aswicahyono et al., 2011). The industrialization has caused Indonesia's structural transformation in the manufacturing industry sector to emerge as a dominant contributor to added value and has overgrown beyond the growth rate of the agricultural sector, it's just only industrial strategies depends on capital accumulation, protection, and high technology have led to polarization and dualism in the development process (Pingali, 2010).

Another fact also shows that the traditional agricultural sector will have an impact on low productivity. The existence of dualism in the manufacturing sector also occurs between small industries and household handicrafts alongside medium and large industries. Besides, the dualism of industrialization in Indonesia mark by the lack of linkages between sectors in the economy, one of the reasons is that currently, industries in Indonesia prioritize industrial development with import substitution. On the other side, the agricultural sector has a strategic role in the Indonesian economy. This condition is understood because the agricultural sector is still the largest provider of employment for the Indonesian population. Besides, the agricultural sector is also the primary economic sector for rural areas, although rural areas also contribute to the most substantial poverty rate in Indonesia. In reality, in the present era, the development of the agricultural sector in Indonesia has been declining. This condition is showing from the contribution of the agricultural sector to the Gross Domestic Product (GDP) where the growth of the agricultural sector is decreasing every year. The trend of the development of the economic growth, agricultural and industrial sectors in Indonesia show in Figure 1. 
Figure 1. The trend of agricultural sector, industry, and GDP growth in Indonesia

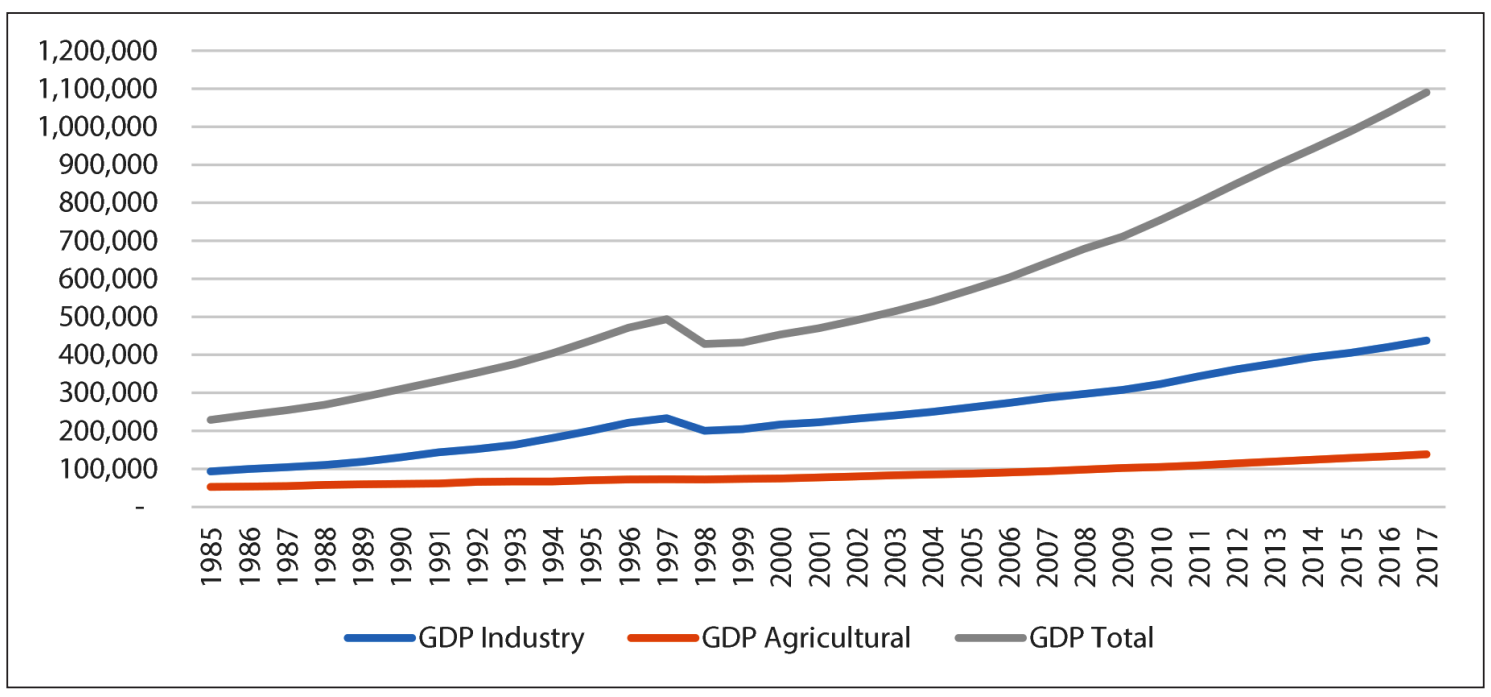

Source: World Bank (2017)s

The role of the agricultural and industrial sectors in Indonesia reflects in the valueadded contribution to the Gross Domestic Product (GDP). In Figure 1 above indicated the trends of the agricultural and industrial sectors with the percentage contribution to GDP in Indonesia, currently the highest share of added value compared to other sectors is the industrial sector with an average of $44.10 \%$, while the agricultural sector is only $16.61 \%$. The data shows that the most added value of the agricultural sector is absorbed in the industrial sector and others. This condition is line with the results of the study by Singh (2010), he found that the agricultural sector can benefit the nonagricultural sector, especially the industrial sector because most of the development of the agricultural sector depends on the provision of modern inputs and technology from the industrial sector.

Indonesia's current economic development is more directed to the development of the industrial sector because the industrial sector considers as a driving force for economic growth compared to other sectors. The contribution of the industrial sector can show from the GDP indicator where the industrial sector contributes the most significant national income every year, and its growth also increases. However, in its practice, the development of the industrial sector cannot be separated from the role of the agricultural sector. Several studies that have been conducted find that the agricultural and industrial sectors are the engine of growth both in terms of providing raw materials, foodstuffs and as input for products produced by other sectors (Lecocq \& Shalizi, 2007; Tiffin \& Irz, 2006).

The empirical approach to evaluating the impact of agriculture on economic growth is useful for developing endogenous growth theories by including the potential contribution of agriculture such as the studies conducted by Botri (2013) and Singh (2010). In addition, the relationship between the agricultural and industrial sector which the interdependence, especially in developing countries has also been studied by Dercon \& Gollin (2014); Lin, (2014); and Mcmillan et al., 2015). Their study found that the growth of the agricultural 
sector contributed to the growth of the industrial sector, but the growth of the industrial sector cannot improve the growth of the agricultural sector.

The starting point from the previous study, there are not many that examine the dynamic relationship between agriculture, industry, and economic growth. This study aims to examine and analyze causality between the agricultural, industrial, and economic sectors in Indonesia. Efforts were made to determine whether the agricultural sector, industrial sector, and economic growth in Indonesia had a causal relationship both in the long and short-term. This study is expected to contribute, first, to improve the implications of government policies for the agricultural and agricultural sectors; second, to give knowledge and development of endogenous growth theories in economic development.

\section{Methods}

This study focused on knowing the relationship between the agricultural, industrial, and economic growth sectors. This study uses secondary data in the form of time-series data during 1985-2017. Data sources obtained from the official website of the World Bank by taking world development indicator data. Variables used in this study include economic growth (real GDP), agricultural added value (AGR), and industrial added value (IND). The details about data and source show in Table 1.

Table 1. Data and Source

\begin{tabular}{|c|c|c|c|}
\hline Variable & Description & Unit & Source \\
\hline AGR & Agricultural added value & (US\$, constant 2010) & $\begin{array}{l}\text { World Development Indicator, } \\
\text { World Bank (2017) }\end{array}$ \\
\hline IND & Industry added value & (US\$, constant 2010) & $\begin{array}{l}\text { World Development Indicator, } \\
\text { World Bank (2017) }\end{array}$ \\
\hline GDP & Economic growth (GDP) & (US\$, constant 2010) & $\begin{array}{c}\text { World Development Indicator, } \\
\text { World Bank (2017) }\end{array}$ \\
\hline
\end{tabular}

Source: World Bank (2017)

The analysis approach by applying the dynamic relationship model with vector error correction model (VECM) Granger causality, consists of three models namely (1) the first model will explain how the industrial added value and economic growth jointly affect the agriculture added value; (2) the second model will explain how the agricultural added value and economic growth jointly affect the industrial added value; and (3) the third model will explain how the agricultural added value and the industrial added value jointly affect the economic growth. Before estimating the model of VEC Granger causality, several steps must be fulfilled, such as testing the data stationary with unit root test with the test of Augmented Dickey-Fuller (ADF-Test), optimum lag test, and Johansen co-integration test (Verbeek, 2012).

The unit root test in this study used the formulated developed by Levin et al. (2002) and Im et al. (2005). The unit root test equation Levin et al. (2002) and Im et al. (2005) considers the ADF criteria as follows: 
$\Delta \ln Y_{t}=\rho_{t} Y_{t-1}+\sum_{j=1}^{\rho_{t}} \delta_{t, j} \Delta \ln Y_{t-j}+\varepsilon_{t}$

Where: $Y_{t}$ is the vector of the main endogenous variables in the study, i.e., economic growth, agriculture added value, and industry added value. The unit root test by Levin et al. (2002) assuming that the parameter accuracy $\rho_{t}$ identical in time series (i.e., $\rho_{t}=\rho$ for all $t$ ), while lag order $\rho_{t}$ can vary freely. This procedure tests of null hypothesis $\rho_{t}=0$ for all t against alternative hypotheses $\rho_{\mathrm{t}}<0$ for all t. Rejection of the null hypothesis indicates the possibility of continuing the data integration process and vice versa.

The unit root test by Im et al. (2005), which is also based on the equation (1), different from the unit root test by Levin et al. (2002), with assumption $\rho$ i become heterogeneous across sections. The unit root test by Im et al. (2005) tests of null hypothesis accepted if $\rho_{\mathrm{t}}=$ 0 against alternative hypotheses $\rho_{t}<0,(t=1, \ldots, t) ; \rho_{t}=0,\left(t=t_{1}, \ldots, t\right)$ for all $t$. Acceptance of alternative hypotheses allows individual series to be integrated. The unit root test by Levin et al. (2002) and Im et al. (2005) can be estimated in data at the level and for the first difference in the form of natural logarithms.

Empirically, this study focuses on the causal impact of the agricultural added value, the industry added value, and economic growth in Indonesia, this study also uses co-integration tests, to see if there is a maximum possibility of Johansen co-integration test (Verbeek, 2012) to determine the long-term relationship between the variables being investigated. In checking Granger causality analysis also needs to be done to get good results from the test results by choosing the right optimal lag length. The Johansen co-integration framework takes its starting point in the vector error correction model (VECM), while the equation can show as follows:

$\mathrm{x}_{\mathrm{t}}=\mathrm{A}_{1} x_{\mathrm{t}-\mathrm{p}}+\ldots+\mathrm{A}_{\mathrm{p}} \mathrm{x}_{\mathrm{t}-\mathrm{p}}+\mathrm{By}_{\mathrm{t}}+\varepsilon_{\mathrm{t}}$

Where: $x_{t}$ is a vector of endogenous variables, and A represents an autoregressive matrix. $y_{t}$ is a deterministic vector and $B$ represents the parameter matrix. $\varepsilon_{t}$ is the vector of innovation, and $\mathrm{p}$ is the lag length.

In order to reveal the direction of causality between the agricultural added value (AGR), the industry added value (IND), and economic growth (GDP) in the context of the timeseries data. Then the VECM Granger causality equation model can be seen as follows:

$$
\begin{aligned}
& \Delta \ln \mathrm{AGR}_{\mathrm{t}}=\alpha_{1 \mathrm{t}}+\sum_{\mathrm{l}=1}^{\mathrm{mIAgr}_{\mathrm{t}}} \beta_{1 \mathrm{t}, \mathrm{l}} \Delta \operatorname{lnAGR}_{\mathrm{t}-1}+\sum_{\mathrm{l}=1}^{\text {mIInd }_{\mathrm{t}}} \gamma_{1 \mathrm{t}, \mathrm{l}} \Delta \operatorname{lnIND}_{\mathrm{t}-1}+\sum_{\mathrm{l}=1}^{\mathrm{mIgdp}} \delta_{2 \mathrm{t}, \mathrm{l}} \Delta \operatorname{lnGDP}_{\mathrm{t}-1}+\mathrm{EC}_{\mathrm{t}-1} \\
& +\varepsilon_{1 \mathrm{t}} \\
& \Delta \operatorname{lnIND}_{\mathrm{t}}=\alpha_{2 \mathrm{t}}+\sum_{\mathrm{l}=1}^{\text {mIAgr }_{\mathrm{t}}} \beta_{2 \mathrm{t}, \mathrm{l}} \Delta \operatorname{lnAGR_{\mathrm {t}-1}}+\sum_{\mathrm{l}=1}^{\text {mIInd }_{\mathrm{t}}} \gamma_{2 \mathrm{t}, \mathrm{l}} \Delta \operatorname{lnIND}_{\mathrm{t}-1}+\sum_{\mathrm{l}=1}^{\mathrm{mIgdp}_{\mathrm{t}}} \delta_{2 \mathrm{t}, \mathrm{l}} \Delta \operatorname{lnGDP}_{\mathrm{t}-1}+\mathrm{EC}_{\mathrm{t}-1} \\
& +\varepsilon_{2 \mathrm{t}} \\
& \Delta \operatorname{lnGDP}_{\mathrm{t}}=\alpha_{3 \mathrm{t}}+\sum_{\mathrm{l}=1}^{\text {mIAgr }_{\mathrm{t}}} \beta_{3 \mathrm{t}, \mathrm{l}} \Delta \ln \mathrm{AGR}_{\mathrm{t}-1}+\sum_{\mathrm{l}=1}^{\text {mIInd }_{\mathrm{t}}} \gamma_{3 \mathrm{t}, \mathrm{l}} \Delta \operatorname{lnIND}_{\mathrm{t}-1}+\sum_{\mathrm{l}=1}^{\mathrm{mIgdp}_{\mathrm{t}}} \delta_{3 \mathrm{t}, \mathrm{l}} \Delta \operatorname{lnGDP}_{\mathrm{t}-1}+\mathrm{EC}_{\mathrm{t}-1} \\
& +\varepsilon_{3 \mathrm{t}}
\end{aligned}
$$


Where $\mathrm{t}$ is time period $(\mathrm{t}=1, \ldots, \mathrm{t})$; 1 is lag of each variable; $\ln$ GDP is GDP real; $\ln A G R$ is the agriculture added value; and InIND is the industry added value; EC is error correction and $\varepsilon_{1 \mathrm{t}}, \varepsilon_{2 \mathrm{t}}, \varepsilon_{3 \mathrm{t}}$ is assuming error rates on the model (error term).

According to Lopez \& Weber (2017) some possibilities will be obtained regarding the value of the coefficients of each of these variables, i.e. (i) for example in the first equation only causality occurs between IND and GDP to AGR, means only $Y_{1 \mathrm{t}} \neq 0$ (rejection of the null hypothesis), whereas all hypotheses $\beta_{1 \mathrm{t}}$ and $\delta_{1 \mathrm{t}}=0$, means between AGR, IND and Y there is no causality with each other (acceptance of the null hypothesis), it indicated that there is at least one relationship or the other; (ii) acceptance of the null hypothesis occurs, if all probability is at $Y_{1 \mathrm{t}}, \beta_{1 \mathrm{t}}$, and $\delta_{1 \mathrm{t}}=0$, which means that none of the variables have a good causal relationship in the same direction (directional) or two-way (bidirectional); (iii) the rejection of the null hypothesis occurs, if there are other possibilities, such as if $Y_{1 \mathrm{t}}, \beta_{1 \mathrm{t}}$, and $\delta_{1 \mathrm{t}} \neq 0$, which means all variables have the possibility of a causality both in the same direction (directional) or two-way (bidirectional).

\section{Result and Discussion}

Before estimating VECM Granger causality, several econometric criteria must fulfill, such as testing the data station with unit root test used criteria Augmented Dickey-Fuller test (ADF-Test), this test developed by Levin et al. (2002) and Im et al. (2005). The results of unit root testing can show in Table 2

Table 2. The Unit Root Test at the First Difference

\begin{tabular}{cccccc}
\hline & ADF test & \multicolumn{3}{c}{ t-Statistic } & note \\
\cline { 3 - 5 } Variable & & $\mathbf{1} \%$ & $5 \%$ & $\mathbf{1 0 \%}$ & \\
\hline$\Delta($ LNAG $)$ & -4.585416 & -3.661661 & -2.960411 & -2.619160 & *stationary \\
$\Delta($ LNIND $)$ & -3.961376 & -3.661661 & -2.960411 & -2.619160 & *stationary \\
$\Delta($ LNGDP $)$ & -4.021836 & -3.661661 & -2.960411 & -2.619160 & *stationary \\
\hline
\end{tabular}

Null Hypothesis: $\Delta($ LNAG); $\Delta($ LNIND); $\Delta($ LNGDP) has a unit root

Lag Length: 0 (Automatic - based on SIC, max lag=8)

*MacKinnon (1996) one-sided p-values.

Table 2 shows the results of unit root testing on the first difference. The result indicates that the variable value added of the agricultural sector (AGR), the added value of the industrial sector (IND), and economic growth (GDP) are stationary, as indicated by the $\mathrm{ADF}$ test value which is higher than the $\mathrm{t}$-statistic value (t-statistic) at the level of $1 \%, 5 \%$, and $10 \%$. Furthermore, this variable can be used to estimate Granger causality with vector error correction model (VECM).

The next step is to determine how long the lag (optimal lag) is right in the causality model. Table 3 shows the results of the optimum Lag test. The results indicate that the determination of the lag length on the data to be used in estimating Granger causality is lag one for the three variables. 
Abdul Bashir. The Causality Between Agriculture, Industry, and Economic Growth

Table 3. The Optimum Lag Test

\begin{tabular}{ccccc}
\hline Optimum lag & $\Delta(\operatorname{InAGR})$ & $\Delta(\operatorname{InIND})$ & $\Delta(\operatorname{InGDP})$ & Joint \\
\hline \multirow{2}{*}{$\Delta$ Lag one } & 8.395358 & 13.35007 & 16.42338 & 28.90772 \\
& {$[0.038510]^{* *}$} & {$[0.003938]^{* * *}$} & {$[0.000928]^{* * *}$} & {$[0.000672]^{* * *}$} \\
\multirow{2}{*}{$\Delta$ Lag two } & 12.96415 & 4.862031 & 5.710544 & 18.47730 \\
& {$[0.004715]^{* * *}$} & {$[0.182183]$} & {$[0.126574]$} & {$[0.030023]^{* *}$} \\
\hline df & 3 & 3 & 3 & 9 \\
\hline
\end{tabular}

Note: Chi-squared test statistics for lag exclusion:

Significant level at ${ }^{* *} 1 \%, * * 5 \%$, and $* 10 \%$

Numbers in [ ] are p-values

The Johansen co-integration test to determine long-term relationships between variables under investigation. In checking causality, Granger causality analysis also needs to be done to get good results from the test results by choosing the right optimal lag length. The Johansen co-integration framework takes its starting point in the vector error correction model (VECM) model. Based on the results of the Johansen co-integration test in Table 4 indicated that the results of the Trace Statistic value are higher than the critical value, as well as the Max-Eigen Statistic value is higher than the critical value. These results indicate that in the long run, there is co-integration in the equation model — the results of the Johansen co-integration test present in Table 4.

Table 4. Johansen Co-integration Test

\begin{tabular}{ccccc}
\hline \multicolumn{5}{c}{ Trace test } \\
\hline Null Hypothesized $\left(\mathrm{H}_{0}\right)$ & Eigenvalue & Trace Statistic & Critical Value 0.05 & Prob. $^{* *}$ \\
\hline None* $^{*}$ & 0.386871 & 33.61646 & 29.79707 & 0.0173 \\
At most 1 & 0.299587 & 18.94106 & 15.49471 & 0.0145 \\
At most 2 & 0.240644 & 8.258526 & 3.841466 & 0.0041 \\
\hline Null Hypothesized $\left(\mathrm{H}_{0}\right)$ & Eigenvalue & Max-Eigen Statistic & Critical Value 0.05 & Prob. $^{* *}$ \\
\hline None & 0.386871 & 14.67539 & 21.13162 & 0.3123 \\
At most 1 & 0.299587 & 10.68254 & 14.26460 & 0.1709 \\
At most 2 & 0.24064 & 8.258526 & 3.841466 & 0.0041 \\
\hline
\end{tabular}

Max-eigenvalue test indicates 4 cointegrating eqn(s) at the 0.05 level

* denotes rejection of the hypothesis at the 0.05 level

**MacKinnon-Haug-Michelis (1999) p-values

The vector error correction model is a form of vector autoregressive (VAR) model that estimate because of the existence of non-stationary but co-integrated data forms. VECM often referred to as a VAR design for non-stationary series that has a co-integration relationship. The VECM specification restores the long-term relationships of endogenous variables in order to 
converge into their co-integration relationships, but still, allow the existence of short-term dynamics. The estimation results of the VEC model can show in Table 5.

Table 5. VECM estimation for long-term causality

\begin{tabular}{|c|c|c|c|c|c|c|}
\hline $\begin{array}{l}\text { Dependent } \\
\text { Variable }\end{array}$ & $\mathrm{C}$ & $\Delta\left(\ln A G R_{t-1}\right)$ & $\Delta\left(\ln \mid N D_{t-1}\right)$ & $\Delta\left(\operatorname{lnGDP}_{t-1}\right)$ & $E C T_{t-1}$ & Summary \\
\hline \multirow{3}{*}{$\Delta(\ln A G R)$} & 0.040 & 0.264 & 0.354 & 0.186 & 0.441 & $R^{2}: 0.507$ \\
\hline & $(0.008)$ & $(0.278)$ & $(0.311)$ & $(0.382)$ & $(0.160)$ & $\begin{array}{c}\text { Adj. } R^{2}: 0.350 \\
\text { F-stat: } 3.232\end{array}$ \\
\hline & {$[4.916]^{* * *}$} & [0.950] & [1.139] & [0.487] & {$[2.750]^{* * *}$} & $\begin{array}{l}\text { AIC: }-5.747 \\
\text { SC: }-5.373\end{array}$ \\
\hline \multirow{3}{*}{$\Delta(\operatorname{InIND})$} & 0.005 & 1.920 & 3.128 & 3.486 & 0.211 & $R^{2}: 0.398$ \\
\hline & $(0.026)$ & $(0.895)$ & $(1.003$ & $(1.233)$ & $(0.517)$ & $\begin{array}{c}\text { Adj. } R^{2}: 0.206 \\
\text { F-stat: } 2.075\end{array}$ \\
\hline & {$[0.179]$} & {$[2.145]^{* *}$} & {$[3.119]^{* * *}$} & {$[2.828]^{* * *}$} & {$[0.408]$} & $\begin{array}{l}\text { AIC: }-3.406 \\
\text { SC: }-3.032\end{array}$ \\
\hline \multirow{3}{*}{$\Delta(\operatorname{lnGDP})$} & 0.012 & 1.486 & 2.538 & 2.698 & 0.555 & $R^{2}: 0.484$ \\
\hline & $(0.021)$ & $(0.717)$ & $(0.803)$ & $(0.987)$ & $(0.414)$ & $\begin{array}{l}\text { Adj. } R^{2}: 0.320 \\
\text { F-stat: } 2.947\end{array}$ \\
\hline & {$[0.580]$} & {$[2.074]^{* *}$} & {$[3.161]^{* * *}$} & {$[2.734]^{* * *}$} & [1.342] & $\begin{array}{l}\text { AIC: }-3.851 \\
\text { SC: }-3.477\end{array}$ \\
\hline
\end{tabular}

Note: Significant level at ${ }^{* * *} 1 \%,{ }^{*} 5 \%$, and ${ }^{*} 10 \%$

The VECM estimation results indicate that of the three models that have estimated indicate there is one model that has a long-term causality relationship. In the estimation of the first model indicated that the variables of agricultural added value, the industrial added value, and economic growth at lag one do not have a significant influence on the agricultural added value. This result can show from the t-test value below the standard value of t-test at 1.98. However, from these results, there are allegations that significant error correction parameters prove the existence of the variable adjustment mechanism affecting in the long run. The amount of adjustment from short-term to long-term is 0.441 . This result shows that there is the validity of the long-term balance relationship between variables. It also implies that $44 \%$ of the imbalance of the previous period shocks reunited into long-run equilibrium in the current period. In other words, there is the long-term directional causality from the industrial added value, economic growth to the agricultural added value. This condition does not occur in the industry, added value, and economic growth. These findings are in line with the results of the study conducted by Akpan et al., (2012); Behera \& Tiwari (2014); and Tiwari \& Suresh (2010).

The second model indicated that the variables of agricultural added value, industrial added value, and economic growth in one lag have a significant influence on the industry added value. This result can show from the t-test value, which is higher than the standard value of t-test 1.98. Statistically, the increase in the agricultural added value in the previous year was from a coefficient value at 1.920 , which meant that an increase at $1 \%$ in the agricultural added value would increase the added value of the industrial sector at $1.92 \%$. Furthermore, the variable lag distribution is the industrial added value in the previous year that has a 
coefficient at 3.128, which means if the industrial added value in the previous year increased at $1 \%$, it would increase the current of industrial added value at $3.13 \%$. Likewise with the previous year's economic growth variable, which has the coefficient value at 3.486, which means that if the economic growth in the previous year increased at $1 \%$, then the industry added value would increase at $3.49 \%$. These findings are in line with the results of the study conducted by Matahir (2012); and Sertoğlu et al., (2017).

The third model indicated that the variables of agricultural added value, industrial added value, and economic growth in the previous year have a significant effect on economic growth. Statistically, the agricultural added value has a coefficient at 1.486 , and this indicates that when the agricultural added value in the previous year increased at $1 \%$, it will encourage the current economic growth at $1.49 \%$. Meanwhile, the variable of industrial added value has a coefficient value at 2.538. Statistically, when the industrial added value in the previous year increased at $1 \%$, it will encourage the current economic growth at $2.54 \%$. Likewise, with the lag variable of economic growth that has the coefficient value at 2.698 , statistically, it indicates that when economic growth in the previous year increased at $1 \%$, it will encourage the current economic growth at $2.69 \%$ assuming that the variables in the model are constant. These findings are in line with the results of the study conducted by Matahir (2012); and Sertoğlu et al., (2017).

After observing the estimation results of the VECM above, the implications of this study model indicate that there is a two-way relationship between the industrial added value and economic growth, in which the two variables influence each other. Besides, these two variables can use as endogenous or exogenous variables in the model. Meanwhile, the variable of the agricultural added value is indicated as an exogenous variable in the model, because when viewed from the estimation results of the model, this variable can only affect other variables and not apply otherwise. The implication in the study model assumes that the agricultural added value can only influence by other value changes such as the consumption value, the exports value, and imports of agricultural products, the extent of productive land, and the increase in human capital and technology used in the production process (Bashir et al., 2018; Dahlman, 2007; Kniivilä, 2004).

The results of diagnostic statistics testing of the data used among them autocorrelation test (serial correlation) using the Lagrange Multiplier test (LM test), the results indicated that the null hypothesis rejected which means that there is no autocorrelation from the residual of the lag specified. The next test is heteroscedasticity test with a cross product. The null hypothesis of heteroscedasticity tests indicated that the null hypothesis rejected, which means there is no heteroscedasticity and no misspecification. Then the normality test using the Jarque-Bera test (JB test) indicated that the null hypothesis is accepted which means that the sample size observed is normally distributed (it can show in Table 6).

The result of estimate the short-term causality model, in the first model testing the null hypothesis ( $\mathrm{H} 0)$ on short-term causality is that past lags of independent variables, namely industrial added value and economic growth jointly not affect the dependent variable, namely the agricultural added value. Statistically, it shows that the Chi-square probability value is higher than 0.05 , then the null hypothesis is accepted, which means that there is 
no short-term relationship between the independent and dependent variables. The same process is repeated in the second model to test short-term causality between past lags of the independent variables, namely agricultural added value and economic growth jointly affect the dependent variable, namely the industrial added value. Statistically, indicating that the Chi-square probability value is smaller than 0.05 , the null hypothesis is rejected, which means that there is a short-term relationship between the independent and dependent variables (it can show in Table 6).

Table 6. VECM estimation for short-term causality

\begin{tabular}{|c|c|c|c|c|}
\hline \multirow{2}{*}{$\begin{array}{l}\text { Dependent } \\
\text { variable }\end{array}$} & \multicolumn{3}{|c|}{ Chi-square \& Probability } & \multirow{2}{*}{ Inference (short-run causality) } \\
\hline & $\Delta\left(\ln A G R_{t-1}\right)$ & $\Delta\left(\ln \mid N D_{t-1}\right)$ & $\Delta\left(\operatorname{lnGDP}_{\mathrm{t}-1}\right)$ & \\
\hline \multirow{2}{*}{$\Delta(\ln A G R)$} & - & 2.561 & 4.289 & $\Delta($ LNIND) on $\Delta($ LNAG): no short-run \\
\hline & - & 0.278 & 0.117 & $\Delta($ LNGDP) on $\Delta($ LNAG): no short-run \\
\hline \multirow{2}{*}{$\Delta(\operatorname{InIND})$} & 5.339 & - & 9.761 & $\Delta($ LNAGR) on $\Delta($ LNIND): short-run \\
\hline & $0.069^{*}$ & - & $0.008^{* * *}$ & $\Delta($ LNGDP) on $\Delta$ (LNIND): short-run \\
\hline \multirow{2}{*}{$\Delta(\operatorname{lnGDP})$} & 6.046 & 12.286 & - & $\Delta($ LNAGR $)$ on $\Delta($ LNGDP): short-run \\
\hline & $0.049^{* *}$ & $0.002^{* * *}$ & - & $\Delta($ LNIND) on $\Delta($ LNGDP): short-run \\
\hline \multicolumn{5}{|c|}{ Diagnostic statistics test } \\
\hline \multicolumn{2}{|c|}{ Serial correlation (LM test) } & \multicolumn{2}{|c|}{ Breusch-Godfrey } & $10.17523[0.3365]$ \\
\hline \multicolumn{2}{|c|}{ Normality test } & \multicolumn{2}{|c|}{ Jarque-Bera test } & $11.30351[0.0794]$ \\
\hline \multicolumn{2}{|c|}{ Heteroscedasticity test } & \multicolumn{2}{|c|}{ Breusch-Pagan-Godfrey } & $110.9251[0.1262]$ \\
\hline
\end{tabular}

Note: Significant level at ${ }^{* * *} 1 \%, * * 5 \%$, and ${ }^{*} 10 \%$

Based on the estimation results indicated that the past lags of agricultural added value and industrial added value jointly affect economic growth. Based on the results of the estimation of the model in Table 6, the implications from the model of this study indicate that in the short term, the industrial added value and economic growth has a two-way relationship, which can affect each other in the short term. Likewise, these two variables jointly not affect the agricultural added value in the short term. Meanwhile, the variable of agricultural added value can affect the industrial added value and economic growth in the short term. This behavior is the same as the estimation of the long-term VEC model presented earlier that the variable of agriculture added value indicated as exogenous variables in the model (Rezitis \& Ahammad, 2015).

Generally, the policy implication of our analysis is that the agricultural sector plays a macroeconomics key role in the Indonesian economy, as evidenced by the role of the agricultural sector in the short and long term can still encourage other sectors to grow, especially the industrial sector. While, the industrial sector is closely related to all economic activities, and in turn with the environment of other macroeconomic policies. The industrial policy may be necessary, although in general, it is not optimal yet, the agricultural sector is far more critical, because Indonesia is a country that has great potential in the agricultural sector. Besides, the changes in the economic structure are predicted as a result of technological advances, making the agricultural sector in this country increasingly lagging. This lag may be a result of excessive regulatory policies, and this must find the root cause, possibility of 
competitiveness, and lack of investment in the primary input supply side. However, this is also a significant economic problem and needs to be addressed through an economic, not sectoral approach (Aswicahyono et al., 2011).

\section{Conclusion}

The findings of this result show that the first model indicates that there is a significant error correction parameter that proves that there is a variable adjustment mechanism in the long run. In other words, there is a long-term directional causality from the industrial added value, economic growth on the agricultural added value. The implication in the study model assumes that the agricultural added value can only be affected by other changes in value such as the consumption value, exports value, and imports of agricultural products, productive land extent, and the increase in human capital and technology used in the production process. Meanwhile, in the second and third models indicate that there is a two-way relationship between the industrial added value and economic growth, in which the two variables affect each other.

In the short term, it indicates that in the short term, the variable of the industrial added value and economic growth has a two-way relationship, which can affect each other in the short term. Meanwhile, the variable of agricultural added value can only affect the industrial added value and economic growth in the short term. These findings support the idea that the agricultural sector plays a vital role in the economy, such as increasing economic growth and growth in other sectors, especially the industrial sector in this case.

\section{References}

Akpan, S. B., Udoka, S. J., \& Okon, U. E. (2012). Examination of Empirical Relationships Between Industrial Activities and Agricultural Policy Outputs in Nigeria (1970-2012). International Journal of Food and Agricultural Economics, 2(1), 13-22.

Aswicahyono, H., Hill, H., \& Narjoko, D. (2011). Indonesian Industrialization: A Latecomer Adjusting to Crises. Working Paper World Institute for Development Economics Research No. 2011, 53.

Awokuse, T. O., \& Xie, R. (2014). Does Agriculture Really Matter for Economic Growth in Developing Countries? Canadian Journal of Agricultural Economics, 63(1), 77-99. https://doi.org/10.1111/cjag.12038.

Bashir, A., Susetyo, D., Suhel., \& Azwardi. (2018). The Relationship Between Economic Growth, Human Capital, and Agriculture Sector: Empirical Evidence from Indonesia. International Journal of Food and Agricultural Economics, 6(4), 35-52.

Behera, D. K., \& Tiwari, M. (2014). Growth and Determinants of Employment in Indian Agriculture. Journal of Land and Rural Studies, 2(1), 43-55. https://doi.org/ $10.1177 / 2321024913515106$.

Botri, V. (2013). Determinants of Intra-industry Trade between Western Balkans and EU15: Evidence from Bilateral Data. International Journal of Economic Sciences and Applied Research, 6(2), 7-23. 
Briones, R., \& Felipe, J. (2013). Agriculture and Structural Transformation in Developing Asia: Review and Outlook. ADB Economics Working Paper Series No. 363.

Cervantes-Godoy, D., \& Dewbre, J. (2010). Economic Importance of Agriculture for Poverty Reduction. OECD Food, Agriculture and Fisheries Working Papers No. 23. https://doi. org/10.1787/5kmmv9s20944-en

Dahlman, C. (2007). Technology, Globalization, and International Competitiveness: Challenges for Developing Countries. In O'Connor and M Kjöllerström (Ed.), Industrial Development for the 21st Century. Hyderabad: Orient Longman, Zed Books and United Nations. 29-83.

Dercon, S., \& Gollin, D. (2014). Agriculture in African Development: Theories and Strategies. The Annual Review of Resource Economics, 6, 471-492. https://doi.org/ 10.1146/annurev-resource-100913-012706.

Dethier, J. J., \& Effenberger, A. (2012). Agriculture and Development: A Brief Review of The Literature. Economic Systems, 36(2), 175-205. https://doi.org/ 10.1016/j. ecosys.2011.09.003

Im, K. S., Pesaran, M. H., \& Shin, Y. (2005). Testing for Seasonal Unit Roots in Heterogeneous Panels. Journal of Econometrics, 115(1), 53-74. https://doi.org/10.1016 /j.econlet.2004.06.018

Kniivilä, M. (2004). Industrial Development and Economic Growth : Implications for Poverty Reduction and Income Inequality. In O'Connor and M Kjöllerström (Ed.), Industrial Development for the 21st Century. Hyderabad: Orient Longman, Zed Books and United Nations. 295-332.

Lecocq, F., \& Shalizi, Z. (2007). How Might Climate Change Affect Economic Growth in Developing Countries? A Review of the Growth Literature with a Climate Lens. World Bank Policy Research Working Paper No. 4315.

Levin, A., Lin, C. F., \& Chu, C. S. J. (2002). Unit Root Tests in Panel Data: Asymptotic and Finite-sample Properties. Journal of Econometrics, 108(1), 1-24. https://doi.org/ s10.1016/S0304-4076(01)00098-7.

Lin, J. Y. (2014). Rural Reforms and Agricultural Growth in China. The American Economic Review, 82(1), 34-51.

Lopez, L., \& Weber, S. (2017). Testing for Granger Causality in Panel Data. IRENE Working Paper No. 17-03.

Loren, B., Hsieh, C. T., \& Zhu, X. (2008). Growth and Structural Transformation in China. In Brandt, L., \& Rawski, T. G. (Ed.), China's Great Economic Transformation. Cambridge: Cambridge University Press. 683-728. https://doi.org/10.1017/CBO9780511754234.018

Matahir, H. (2012). The Empirical Investigation of the Nexus between Agricultural and Industrial Sectors in Malaysia. International Journal of Business and Social Science, 3(8), 225-231.

Mcmillan, J., Whalley, J., Zhu, L., \& Mcmillan, J. (2015). The Impact of China’s Economic Reforms on Agricultural Productivity Growth. Journal of Political Economy, 97(4), 781-807. 
Abdul Bashir. The Causality Between Agriculture, Industry, and Economic Growth

Mondal, D. (2014). Agricultural Productivity and Industrialization: A reformulation. New Delhi: Indian Statistical Institute.

Olmstead, A. L., \& Rhode, P. W. (2007). Conceptual Issues for the Comparative Study of Agricultural Development. International Centre for Economic Research (ICER) Working Papers 18-2006.

Pingali, P. (2010). Agriculture Renaissance: Making "Agriculture for Development" Work in the 21st Century. In Rausser, G. C. Handbook of Agricultural Economics, 1st ed., Vol. 4, 3867-3894. Burlington: Academic Press, Elsevier BV. https://doi.org/10.1016/ S1574-0072(09)04014-6

Rezitis, A. N., \& Ahammad, S. M. (2015). Investigating Agricultural Production Relations across Bangladesh, India and Pakistan Using Vector Error Correction and MarkovSwitching Models. Agricultural Economics Research Review, 28(1), 57-72. https://doi. org/10.5958/0974-0279.2015.00004.X

Sahoo, K., \& Sethi, N. (2012). Investigating the Impact of Agriculture and Industrial Sector on Economic Growth of India. OIDA International Journal of Sustainable Development, $5(5), 11-22$.

Sertoğlu, K., Ugural, S., \& Bekun, F. V. (2017). The Contribution of Agricultural Sector on Economic Growth of Nigeria. International Journal of Economics and Financial Issues, 7(1), 547-552.

Singh, T. (2010). Does International Trade Cause Economic Growth? A Survey. World Economy, 33(11), 1517-1564. https://doi.org/10.1111/j.1467-9701.2010.01243.x

Souza, J. P. De. (2014). Growth Complementarity Between Agriculture and Industry: Evidence from a Panel of Developing Countries. Economics Department Working Paper Series No. 177.

Stringer, R., \& Pingali, P. (2004). Agriculture's Contributions to Economic and Social Development. Electronic Journal of Agricultural and Development Economics, 1(1), 1-5.

Tiffin, R., \& Irz, X. (2006). Is Agriculture the Engine of Growth? Agricultural Economics, 35, 79-89.

Timmer, C. P. (1988). The Agricultural Transformation. In Chenery, H., \& Srinivasan, T. N. Development Economics. 276-328. USA: Elsevier Science Publishers.

Tiwari, A., \& Suresh, K. G. (2010). Relationship Between Industry, Agriculture, Service Sectors and GDP: The Indian Experience. International Journal of Economics and Business, 1(1), 1-16.

Urbanchuk, J. M. (2009). Contribution of The Ethanol Industry to The Economy of The United States. In Biodiesel Industry Stands Ready to Meet 2009 Goals (pp. 1-11). United States: LECG Corporation.

Verbeek, M. (2012). A Guide to Modern Econometrics (2nd edition). England: John Wiley \& Sons Ltd. 